\title{
Correspondence
}

\section{DNA-validated parthenogenesis: first case in a captive Cuban boa (Chilabothrus angulifer)}

\author{
Fernanda Seixas ${ }^{1}$, Francisco Morinha ${ }^{2}$, Claudia Luis 33 , Nuno Alvura ${ }^{3}$ \& Maria dos Anjos Pires ${ }^{1}$ \\ ${ }^{1)}$ Laboratório de Histologia e Anatomia Patológica, Escola de Ciências Agrárias e Veterinárias, CECAV, Quinta de Prados, \\ 5000-801 Vila Real, Portugal \\ ${ }^{2)}$ Department of Evolutionary Ecology, National Museum of Natural Sciences (MNCN), Spanish National Research Council (CSIC), \\ José Gutiérrez Abascal 2, 28006 Madrid, Spain \\ 3) Zoo da Maia, Rua da Igreja, S/N, 4470-184 Maia, Portugal
}

Corresponding author: MARIA DOs ANJOS PIREs, e-mail: apires@utad.pt

Manuscript received: 24 September 2019

Accepted: 15 December 2019 by Arne Schulze

Parthenogenesis is a natural form of asexual reproduction in which offspring are produced from unfertilised eggs (Neaves \& Baumann 2011, van Der Kool \& Schwander 2015). This uncommon reproductive strategy has been reported in less than $0.1 \%$ of vertebrate species, nevertheless including a wide range of taxa (i.e. fishes, amphibians, reptiles, birds and mammals), even in wild populations (NeAves \& BAUmAnN 2011, Booth et al. 2012, VAN DeR Kooi \& SCHWAnder 2015, Dudgeon et al. 2017, Allen et al. 2018). Parthenogenetic reproductive events have caught the attention of evolutionary and conservation biologists since the absence of genetic recombination accelerates the accumulation of deleterious mutations in parthenogenetic individuals, which may also have implications in the management and conservation of the species (ENNOs et al. 2005, HeDriCK 2007, LAMPERT 2008). In fact, parthenogenesis has been related to an increased incidence of abortive events, stillbirths, and embryonic and developmental abnormalities (e.g. anophthalmia, microphthalmia, encephalocoele and head foreshortening) in several species (Billy 1986, Bоотн \& Schuett 2016, Allen et al. 2018).

Obligate parthenogenesis is a biological process in which all individuals within a species reproduce asexually (VAN DER KooI \& Schwander 2015, Booth \& SchuetT 2016). Among vertebrates, this reproductive strategy is restricted to Squamate reptiles, being reported in various lizard species and one snake (Indotyphlops braminus) (WYNN et al. 1991, Kearney et al. 2009, Booth \& Schuett 2016). The occasional occurrence of parthenogenesis in individuals of a species that normally reproduces sexually (i.e. facultative parthenogenesis - FP) was first mentioned in birds in the late 18oos (OELLACHER 1872). The phenomenon of
FP has been reported in various species of major vertebrate groups including reptiles, birds and elasmobranchs (sharks and rays) (Booth \& Schuett 2016, Harmon et al. 2016, DUdGEON et al. 2017, RAMACHANDRAN \& MCDANIEL, 2018). Most FP events were documented in captive females after long periods without contact with male conspecifics during their reproductive lifetime (LAMPERT 2008, ВоOTH \& Schuet T 2016). However, parthenogenesis has recently been reported in both wild snake populations (Воотн et al. 2012, CAlvete et al. 2018) and females housed with males (Bоотн et al. 2014), suggesting that its occurrence may be more frequent in vertebrates than previously thought. In addition, the reproductive viability of parthenogenetic offspring has been observed in some species, which highlights the ecological and evolutionary significance of this reproductive strategy (CALvETE et al. 2018). Nevertheless, the biological basis and mechanisms underlying parthenogenesis remain mostly unknown (BоOTH \& SCHUETT 2016, Dudgeon et al. 2017, SHibata et al. 2017).

Accurate identification and characterization of parthenogenesis in captive individuals of non-model species may provide important data towards understanding the frequency, causes, consequences and biological mechanisms of asexual reproduction among vertebrates (FujITA \& Moritz 2009, NEAVES \& BAUMANN 2011). The occurrence of FP has been described in at least six snake families, namely Boidae, Pythonidae, Viperidae, Acrochordidae, Colubridae and Elapidae (Boотн \& Schuett 2016, Shibata et al. 2017, Allen et al. 2018). Among boid snakes (Boidae family), parthenogenesis has been recorded and validated by genetic analysis in Boa constrictor and Eunectes murinus, as well as in two species of the genus Epicrates (E. maurus 


\section{Correspondence}

and E. cenchria), closely related to the genus Chilabothrus (Booth et at. 2011a, 2011b, KinNey et al. 2013, SHibATA et al. 2017). Various FP events confirmed by genetic analysis have also been reported in Pythonidae (Python bivittatus, $P$. regius and Malayopython reticulatus, GROоT et al. 2003, Booth et al. 2014), Viperidae (Agkistrodon contortrix, JoRDAN et al. 2015, CALvete et al. 2018), Colubridae (Thamnophis marcianus and T. couchii, GERMANO \& SMITH 2010, REYNOLDs et al. 2012), and Elapidae (Oxyuranus scutellatus and Acanthophis antarcticus, Allen et al. 2018). The application of molecular techniques greatly improved the characterization of FP events in wild and captive snakes. However, to understand the evolutionary significance of this alternative reproductive strategy it is essential to increase the effort to detect evidence of new potential FP occurrences.

Here, we report two interesting reproductive events recorded in a captive female Cuban boa (Chilabothrus angulifer) isolated from males for 11 years. These occurrences could be explained by two hypotheses: (i) long-term sperm storage from the last mating event or (ii) parthenogenetic reproduction. We applied molecular and histopathological methodologies to evaluate both hypotheses, providing the first evidence of facultative parthenogenesis in a Cuban boa.

On September 20, 2017, a 20-year-old captive female $\mathrm{Cu}$ ban boa from the Zoo da Maia (Maia, Portugal) collection gave birth to a stillborn and deposited multiple non-embryonated eggs. This female, added to the zoological collection in 1999, has had no contact with a male since 2006 when its mate died. Previously, in 2013, this female had delivered a yellowish mass of non-developing eggs and a dead neonate, that has been preserved in $10 \%$ buffered formalin. The offspring from these two deliveries, one fresh and the other formalin-fixed, were analysed in the Histology and Anatomical Pathology Laboratory of Trás-os-Montes e Alto Douro University (UTAD). Tissues samples were processed for histopathology applying the routine staining techniques, with haematoxylin and eosin (HE), for light microscopy.

The DNA isolation from the formalin-fixed specimen (neonate 2013) was carried out using the Quick-DNA Miniprep Plus Kit (Zymo Research), according to the manufacturer's recommended protocol, with some additional steps before sample digestion. Briefly, a mixture of different tissues (liver, lung, gut and skin) was sliced into small pieces with a scalpel. Then the tissues were washed with Phosphate-buffered saline (PBS) during $24 \mathrm{~h}$ (the buffer was replaced twice). The DNA extraction from muscle tissues of the neonate born in 2017 was performed using the NZY Tissue gDNA Isolation kit (Nzytech). The mother's DNA was isolated from her blood using the NZY Blood gDNA Isolation kit (Nzytech). Both extractions were performed following the standard protocols recommended by the manufacturer.

Thirteen microsatellite markers previously characterised for boid species were analysed: $\mu$ sat $1, \mu$ sat 10 , $\mu$ sat

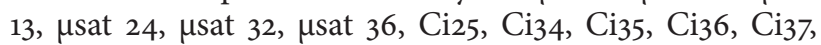
55 HDZ554, and 55 HDZ617 (RAmanana et al. 2009, TzIKA et al. 2009, Воотн et al. 2011b, Reynolds et al. 2014). Prescreening of microsatellite variations between mother and offspring samples was performed using high-resolution melting (HRM) analysis (MADER et al. 2008, LOMBAL et al. 2015). PCR amplification and melting acquisition were carried out using a QuantStudio 3 Real-Time PCR System (Applied Biosystems). The reaction mixture was prepared to a $20 \mu \mathrm{l}$ final volume containing $10 \mu \mathrm{l}$ of MeltDoctor HRM Master Mix (Applied Biosystems), 5 pmol of each primer and $5 \mathrm{ng}$ of genomic DNA. All PCR reactions were performed in duplicate. The amplification protocol was run as follows: 1 cycle of $95^{\circ} \mathrm{C}$ for $10 \mathrm{~min} ; 40$ cycles of $95^{\circ} \mathrm{C}$ for $15 \mathrm{~s}, 60^{\circ} \mathrm{C}$ for $1 \mathrm{~min}$ (fluorescence signal was captured at the end of each cycle); 1 cycle of $95^{\circ} \mathrm{C}$ for $15 \mathrm{~s}, 60^{\circ} \mathrm{C}$ for $1 \mathrm{~min}$ and then sequential temperature increments of $0.025^{\circ} \mathrm{C} / \mathrm{s}$ with temperature ranging from $60^{\circ} \mathrm{C}$ to $95^{\circ} \mathrm{C}$, with continuous fluorescence measurements. The melting curve data were analysed using the QuantStudio Design \& Analysis software v.1.4 (Applied Biosystems) and the High Resolution Melting (HRM) Software v.3.o.1 (Thermo Fisher Scientific). The differences in melting-curve shapes allowed the characterisation of the microsatellite allelic variability. Forward primers of the microsatellites with variations among samples were labelled with 6-FAM to determine the genotypes using capillary electrophoresis. PCR amplifications were performed to a total volume of $20 \mu$ l containing $10 \mu$ of $2 \times$ MyTaq HS Mix (Bioline), 5 pmol of each primer and 5 ng of DNA. PCR thermal conditions were as follows: initial denaturation at $95^{\circ} \mathrm{C}$ for $5 \mathrm{~min}$, followed by 35 cycles of $95^{\circ} \mathrm{C}$ for $30 \mathrm{~s}, 60^{\circ} \mathrm{C}$ for $1 \mathrm{~min}, 72^{\circ} \mathrm{C}$ for $30 \mathrm{~s}$ and a final extension at $60^{\circ} \mathrm{C}$ for $10 \mathrm{~min}$. Amplified fragments were submitted to electrophoresis on an ABI PRISM 3130xl Genetic Analyzer (Applied Biosystems) using the GeneScan 500 LIZ size standard. Allele sizes were determined using Peak Scanner v.3.0.2 (Thermo Fisher Cloud).

Our results support the first evidence of FP in the $\mathrm{Cu}$ ban boa (Chilabothrus angulifer). Macroscopically, both reptiles corresponded to fully developed stillborn snakes that showed no morphological alterations except in the 2017 specimen (\#2), which presented bilateral anophthalmia (Fig. 1). Microscopic examination of organs showed no alterations and the inspection of the reproductive system confirmed both to be female. Of the 13 microsatellite loci screened, two markers ( $\mu$ sat 13 and Ci34) did not amplify or they generated non-specific PCR products. The highresolution melting (HRM) analysis allowed the identification of four microsatellite loci ( $\mu$ sat 10, $\mu$ sat 24, $\mathrm{Ci}_{3} 6$ and Ci37) with allelic variability between mother and offspring samples. No evidence of allelic variability was detected in the remaining loci for the samples analysed. These results were validated using capillary electrophoresis to determine allele sizes for all polymorphic markers and for two nonpolymorphic loci (Table 1). Maternal heterozygosity was observed for polymorphic loci and a homozygosity pattern was obtained for the non-polymorphic loci analysed (Table 1). The offspring were homozygous for all microsatellite loci, always carrying an allele present in the mother ( $\mathrm{Ta}$ ble 1). The locus $\mathrm{Ci} 37$ is a potential null allele in the neonate of 2013 since the amplification failed using different DNA samples and PCR conditions. 
Correspondence

Table 1. Genotypes of mother and offspring characterised for the potentially parthenogenic Cuban boa (Chilabothrus angulifer)

\begin{tabular}{lcccccc}
\hline Individual & $\mu$ sat 10 & $\mu$ sat 24 & Ci35 & Ci36 & Ci37 & 55HDZ617 \\
\hline Mother & $401 / 409$ & $215 / 217$ & $318 / 318$ & $220 / 228$ & $278 / 298$ & $185 / 185$ \\
Neonate 2013 & $409 / 409$ & $217 / 217$ & $318 / 318$ & $220 / 220$ & - & $185 / 185$ \\
Neonate 2017 & $409 / 409$ & $215 / 215$ & $318 / 318$ & $228 / 228$ & $298 / 298$ & $185 / 185$ \\
\hline
\end{tabular}

The allele homozygosity in the offspring, carrying only maternal alleles, was similar to previous FP cases reported for boid species (BоотH et at. 2011a, 2011b, KinNEY et al. 2013, SHibata et al. 2017). In the Boidae family (for genera Boa and Epicrates), parthenogenesis was initially detected in all-female litters (Воотн et at. 2011a, 2011b). Similarly, the two stillborn analysed in this study were both females. Accidental FP in captive individuals generally occurs after long periods of isolation from mates (Bоотн \& Schuet 2016 ). The female in this study has had no contact with any conspecific male for 13 years now. Prolonged sperm storage has been documented in various snake species, but the longest time period of suspected sperm storage reported for a snake was seven years and six months (Magnusson 1979, Birkhead \& MØller 1993, Booth \& SchuetT 2011). In our case we described the lack of male genetic contribution to the offspring using molecular analysis, thus excluding prolonged sperm storage. The high levels of homozygosity detected in the offspring are a characteristic of the parthenogenetic mode explained by terminal fusion automixis (BоOTH et at. 2011a, 2011b), as recently inferred for long-term captive copperheads (Agkistrodon contortrix) and cottonmouths (A. piscivorus) (SHIBATA et al. 2017, Allen et al. 2018).

Genome-wide homozygosity of parthenogenetic offspring may be related to the development of malformations (Bоoтн et al. 2012). Embryos and stillborn offspring with developmental abnormalities have been associated with parthenogenetic events in reptiles (BILly 1986, Воотн \& Schuett 2016, Allen et al. 2018). The morphological evaluation of the Cuban boa neonate born in 2017 evidenced bilateral anophthalmia, a malformation found in parthenogenetic offspring of other reptile species (BILLY 1986).
In conclusion, we identified and described a probable first record of FP in the Cuban boa supported by specimen history and molecular markers. This may have important ecological and evolutionary implications, including the improved understanding of this reproductive strategy and its frequency in captivity, and possibly in the wild, as recorded for some species (Воотн et al. 2012, FiELDs et al. 2015, CALvete et al. 2018). The increasing number of reports on parthenogenic births in a wide range of snakes and other vertebrates also points to the evolutionary significance of this reproductive phenomenon, as yet poorly understood, making it a research field with high potential (LAMPERT 2008, AVISE 2015). Therefore, we encourage zoo workers, veterinarians, curators, wildlife managers and researchers to pay attention and to investigate further evidence towards abnormal births in this species and related taxa, since these events may be easily overlooked.

\section{Acknowledgements}

The authors acknowledge the technical support of Ligia Lourenço. F.M. was supported by a Juan de la Cierva postdoctoral fellowship (FJCI-2017-32055). This work was funded by the project UID/ CVT/00772/2013 and UIC/CVT/00772/2016 supported by the Portuguese Science and Technology Foundation (FCT).

\section{References}

Allen, L., K. L. Sanders \& V. A. Thomson (2018): Molecular evidence for the first records of facultative parthenogenesis in elapid snakes. - Royal Society Open Science, 5: 171901.

Avise, J. C. (2015): Evolutionary perspectives on clonal reproduction in vertebrate animals. - Proceedings of the National Academy of Sciences of the United States of America, 112: 8867-8873.

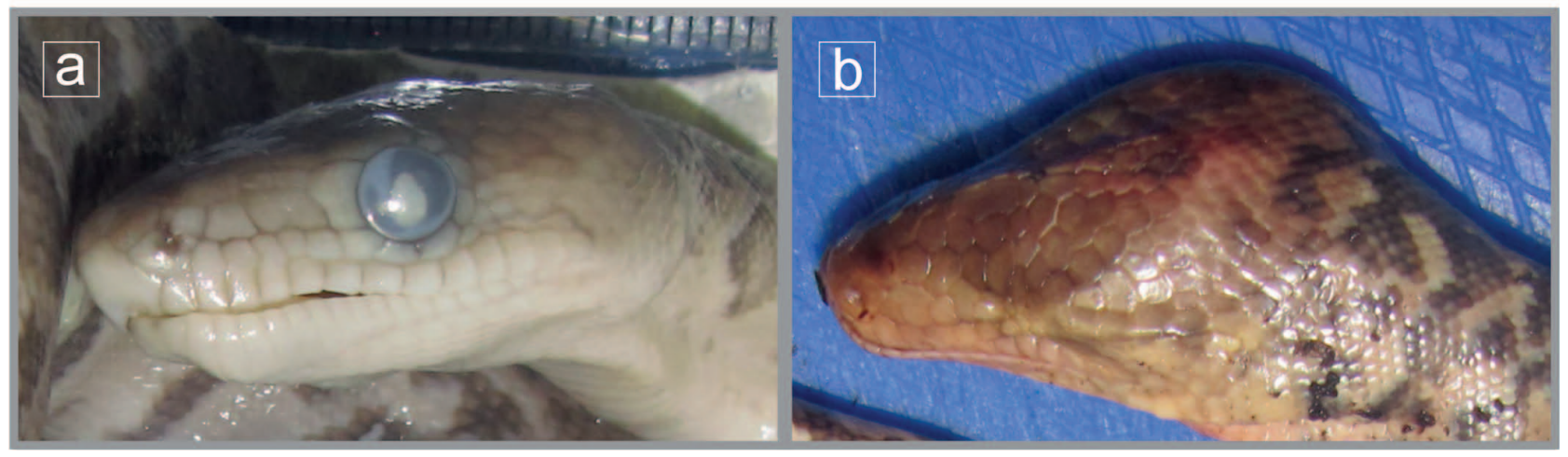

Figure 1. Neonates of the Cuban boa (Chilabothrus angulifer): (a) Neonate from 2013 with a normal head; (b) Neonate from 2017 with bilateral anophthalmia. 


\section{Correspondence}

Billy, A. J. (1986): Developmental deformities in the parthenogenetic lizard Cnemidophorus uniparens (Teiidae) and the "anomalous male" phenomenon. - Canadian Journal of Zoology, 64: 2418-2424.

Birkhead, T. R. \& A. P. Møller (1993): Sexual selection and the temporal separation of reproductive events: sperm storage data from reptiles, birds and mammals. - Biological Journal of the Linnean Society, 50: 295-311.

Воотн, W. \& G. W. Sснuetт (2016): The emerging phylogenetic pattern of parthenogenesis in snakes. - Biological Journal of the Linnean Society, 118: 172-186.

Воотн, W. \& G. W. Schuetт (2011): Molecular genetic evidence for alternative reproductive strategies in North American pitvipers (Serpentes, Viperidae): long-term sperm storage and facultative parthenogenesis. - Biological Journal of the Linnean Society, 104: 934-942.

Booth, W., C. F. Smith, P. H. Eskridge, S. K. Hoss, J. R. MendelSON \& G. W. SCHUETT (2012): Facultative parthenogenesis discovered in wild vertebrates. - Biology Letters, 8: 983-985.

Booth, W., D. H. Johnson, S. Moore, C. Schal \& E. L. Vargo (2011a): Evidence for viable, non-clonal but fatherless Boa constrictors. - Biology Letters, 7: 253-256.

Booth, W., L. Million, R. G. Reynolds, G. M. Burghardt, E. L. Vargo, C. Schal, A. C. Tzika \& G. W. Schuett (2011b): Consecutive virgin births in the New World boid snake, the Colombian rainbow boa, Epicrates maurus. - Journal of Heredity, 102: 759-763.

Boоth, W., G. W. Schuett, A. Ridgway, D. W. Buxton, T. A. Caston, G. Bastone, C. Bennett \& W. McMahan (2014): New insights on facultative parthenogenesis in pythons. - Biological Journal of the Linnean Society, 112: 461-468.

Calvete, J. J., N. R. Casewell, U. Hernández-Gusmán, S. Quesada-Bernat, L. Sanz, D. R. Rokyta, D. Storey, L.-O. AlbuLescu, W. Wüster, C. F. Smith, G. W. Schuett \& W. Boоth (2018): Venom Complexity in a Pitviper produced by facultative parthenogenesis. - Scientific Reports, 8: 11539.

Dudgeon, C. L., L. Coulton, R. Bone, J. R. Ovenden \& S. ThoMAS (2017): Switch from sexual to parthenogenetic reproduction in a zebra shark. - Scientific Reports, 7: 40537.

Ennos, R. A., G. C. French \& P. M. Hollingsworth (2005): Conserving taxonomic complexity. - Trends in Ecology \& Evolution, 20: $164-168$.

Fields, A. T., K. A. Feldheim, G. R. Poulakis \& D. D. Chapman (2015): Facultative parthenogenesis in a critically endangered wild vertebrate. - Current Biology, 25: R446-R447.

Fujita, M. K. \& C. Moritz (2009): Origin and evolution of parthenogenetic genomes in lizards: current state and future directions. - Cytogenetics and Genome Research, 127: 261-272.

Germano, D. J. \& P. T. Smith (2010): Molecular evidence for parthenogenesis in the Sierra garter snake, Thamnophis couchii (Colubridae). - The Southwestern naturalist, 55: 280-282.

Groot, T. V. M., E. Bruins \& J. A. J. Breeuwer (2003): Molecular genetic evidence for parthenogenesis in the Burmese python, Python molurus bivittatus. - Heredity, 90: 130-135.

Harmon, T. S., T. Y. Kamerman, A. L. Corwin \& A. B. Sellas (2016): Consecutive parthenogenetic births in a spotted eagle ray Aetobatus narinari. - Journal of Fish Biology, 88: 741-745.

HedRICK, P. W. (2007): Virgin birth, genetic variation and inbreeding. - Biology Letters, 3: 715-716.

Jordan, M. A., N. Perrine-Ripplinger \& E. T. Carter (2015): An independent observation of facultative parthenogenesis in the copperhead (Agkistrodon contortrix). - Journal of Herpetology, 49: $118-121$.

Kearney, M., M. K. Fujita \& J. Ridenour (2009): Lost sex in the reptiles: constraints and correlations. - pp. 447-474 in: ScHöN, I., K. Martens \& P. Dijk (eds): Lost sex. - Springer, Dordrecht.

Kinney, M. E., R. F. Wack, R. A. Grahn \& L. Lyons (2013): Parthenogenesis in a Brazilian rainbow boa (Epicrates cenchria cenchria). - Zoo Biology, 32: 172-176.

LAMPERT, K. P. (2008): Facultative parthenogenesis in vertebrates: reproductive error or chance? - Sexual Development, 2: 290301.

Lombal, A. J., T. J. Wenner \& C. P. Burridge (2015): Assessment of high-resolution melting (HRM) profiles as predictors of microsatellite variation: an example in Providence Petrel (Pterodroma solandri). - Genes \& Genomics, 37: 977-983.

MAder, E., B. Lukas \& J. NovaK (2008): A strategy to setup codominant microsatellite analysis for high-resolution-melting-curveanalysis (HRM). - BMC Genetics, 9: 69.

Magnusson, W. E. (1979): Production of an embryo by an Acrochordus javanicus isolated for seven years. - Copeia, 4: 744-745.

Neaves, W. B. \& P. Baumann (2011): Unisexual reproduction among vertebrates. - Trends in Genetics, 27: 81-88.

Oellacher, J. (1872): Die Veränderung des unbefruchteten Keimes des Hühnereis im Eileiter und bei Bebrütungsversuch. - Zeitschrift für wissenschaftliche Zoologie, 22: 181-234.

Ramachandran, R. \& C. D. McDaniel (2018): Parthenogenesis in birds: a review. - Reproduction, 155: R245-R257.

Ramanana, M. A., C. A. Bailey, G. D. Shore, O. Ramilijaona, R. A. BRENNEMAN \& E. E. Louis (2009): Characterization of 20 microsatellite marker loci in the Malagasy tree boa (Sanzinia madagascariensis madagascariensis). - Conservation Genetics, 10: 1953 .

Reynolds, R. G., A. R. Puente-Rolón, K. Kolodzaike \& T. ButLER-SMITH (2014): Isolation and characterization of 23 novel polymorphic microsatellite markers from the endangered Puerto Rican boa (Chilabothrus inornatus) using paired-end Illumina shotgun sequencing. - Conservation Genetics Resources, 6: 107-109.

Reynolds, R. G., W. Booth, G. W. Schuett, B. M. Fitzpatrick \& G. M. BuRghARDT (2012): Successive virgin births of viable male progeny in the checkered gartersnake, Thamnophis marcianus. Biological Journal of the Linnean Society, 107: 566-572.

Shibata, H., S. Sakata, Y. Hirano, E. Nitasaka \& A. Sakabe (2017): Facultative parthenogenesis validated by DNA analyses in the green anaconda (Eunectes murinus). - Plos One, 12: e0189654.

Tzika, A. C., C. Remy, R. Gibson \& M. C. Milinkovitch (2009): Molecular genetic analysis of a captive-breeding program: the vulnerable endemic Jamaican yellow boa. - Conservation Genetics, 10: 69-77.

VAN DeR KooI, C. J. \& T. Schwander (2015): Parthenogenesis: birth of a new lineage or reproductive accident? - Current Biology, 25: R659-R661.

Wynn, A. H., T. Hikida, A. Mori, H. ОтA \& M. Matsui (1991): Morphological variation, karyotype and reproduction of the parthenogenetic blind snake, Ramphotyphlops braminus, from the insular region of East Asia and Saipan. - Amphibia-Reptilia, 12: $181-193$. 